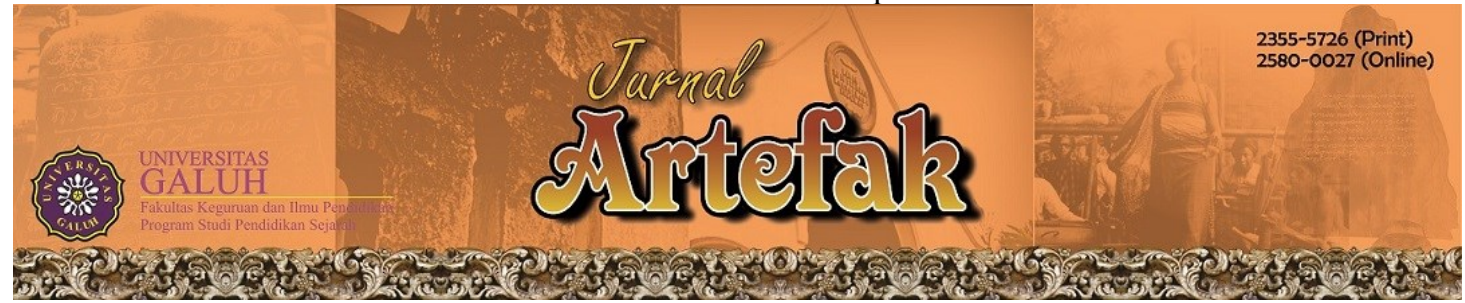

https://jurnal.unigal.ac.id/index.php/artefak/article/view/5127

\title{
PEMBELAJARAN PENDIDIKAN KEWARGANEGARAAN BERBASIS KEARIFAN LOKAL MASYARAKAT KUTA DALAM MEMBENTUK KARAKTER WARGA NEGARA BERWAWASAN LINGKUNGAN
}

\author{
Bali Widodo ${ }^{1}$, Egi Nurholis ${ }^{2}$ \\ ${ }^{1}$ Institut Teknologi Nasional Bandung, Indonesia \\ ${ }^{2}$ Universitas Galuh Ciamis, Indonesia \\ E-mail: baliw@itenas.ac.id ${ }^{1}$, eginurholis@gmail.com ${ }^{2}$ \\ Sejarah Artikel: Diterima 1-Maret-2021 Disetujui 15-Maret-2021 Dipublikasikan -April-2021
}

\begin{abstract}
Abstrak
Perusakan lingkungan sebagai akibat ulah manusia dapat mengancam kehidupan manusia itu sendiri. Penelitian ini bertujuan untuk mengkaji pengembangan pembelajaran Pendidikan Kewarganegaraan yang berbasis kearifan lokal masyarakat Kuta dalam membentuk karakter warga negara yang berwawasan lingkungan. Penelitian ini adalah penelitian konseptual dengan metode library research, yakni mengumpulkan data-data dari laporan penelitian, artikel ilmiah atau sumber lain yang relevan dengan topik. Analisis dari pembahasan ini menjelaskan bahwa kearifan lokal masyarakat Kuta yang secara turun temurun menjaga kelestarian hutan adat atau Leuweung Gede dapat membentuk karakter yang peduli akan lingkungan hidup yang baik dan bersih. Maka untuk membentuk karakter peduli lingkungan peserta didik perlu dilakukan upaya: 1) revitalisasi epistemologi Pendidikan Kewarganegaraan; 2) penanaman nilai keadaban masyarakat lokal terhadap lingkungan dalam proses pembelajaran; Upaya ini kemudian diterapkan dalam pembelajaran Pendidikan Kewarganegaraan sehingga dapat menguatkan karakter peduli lingkungan peserta didik sebagai warga negara.
\end{abstract}

Kata Kunci: Pendidikan Kewarganegaraan, Kearifan Lokal, Masyarakat Kuta, Wawasan Lingkungan

\begin{abstract}
Environmental destruction as a result of human activity can threaten human life itself. This study aims to examine the development of Citizenship Education learning based on the local wisdom of the Kuta community in shaping the character of citizens with an environmental perspective. This research is conceptual research using the library research method, which collects data from research reports, scientific articles, or other sources relevant to the topic. The analysis of this discussion explains that the local wisdom of the Kuta community which has been hereditary to preserve the customary forest or Leuweung Gede can form a character that cares about a good and clean environment. So to form a character that cares about the environment, students need to make efforts: 1) revitalizing the epistemology of Citizenship Education; 2) inculcating the value of the local community's civility towards the environment in the learning process; This effort is then applied in Citizenship Education learning so that it can strengthen the character of caring for the environment of students as citizens.
\end{abstract}

Keyword: Citizenship Education, Local Wisdom, Kuta Community, Environmental Insights

\section{PENDAHULUAN}

Proses kerusakan lingkungan berjalan secara cepat dan meningkat, membuat lingkungan alam dan sekitarnya makin tidak nyaman bagi manusia, bahkan jika terus berjalan akan membuatnya makin tidak cocok lagi untuk kehidupan manusia dan makhluk 
hidup lainnya. Budaya yang menganggap bahwa manusia yang paling penting (antroposentris) harus diubah menjadi budaya ekosentris. (Soemarwoto, 2001:86)

Kesadaran dan kepedulian warga negara terhadap upaya pelestarian lingkungan tergolong masih rendah. Hal ini disebabkan banyak aspek diantaranya aspek spiritual warga masyarakat dalam mengelola kelestarian lingkungan, pendidikan lingkungan yang belum optimal, besarnya masyarakat miskin yang masih bergantung kepada alam, aspek hukum dan penegakannya yang belum optimal (Yuniarto, 2011:1). Isu lingkungan menjadi salah satu hak asasi manusia yang tecantum dalam UndangUndang Dasar Negara Republik Indonesia Tahun 1945 pasal 28H ayat (1) yang menegaskan bahwa "Setiap orang berhak hidup sejahtera lahir dan batin, bertempat tinggal, dan mendapatkan lingkungan hidup yang baik dan sehat serta berhak memperoleh pelayanan Kesehatan". Pasal 28H ayat (1) tersebut mencerminkan konstitusi hijau (green constitution) dimana negara menjamin hak warga negaranya untuk mendapatkan lingkungan hidup yang baik dan sehat. Lebih lanjut Herlina, (2015:3) mengemukakan muara dari semua masalah lingkungan adalah pembangunan yang dilakukan tanpa memperhatikan faktor lingkungan yang pada gilirannya akan menimbulkan kerusakan dan pencemaran lingkungan hidup. Tindakan yang mencemari lingkungan sama artinya dengan mematikan hidup itu sendiri (Suparni, 1994:18)

\section{Menurut Fitriasari}

(2017:57) permasalahan kerusakan dan pencemaran lingkungan bukan lagi masalah lokal atau regional tapi sudah merupakan masalah global. Negara-negara di dunia menyadari bahwa masalah lingkungan saling berkaitan dan dibutuhkan oleh seluruh umat manusia tanpa dibatasi oleh teritorial negara. Banyak perjanjian internasional yang sudah dibuat bahkan sudah diraftifikasi oleh negara-negara di dunia. Beberapa negara menunjukan komitmennya dalam perlindungan lingkungan dengan konsep pembagunan berkelanjutan. Berbagai konferensi tentang lingkungan pun banyak dilakukan, diantaranya: a) Konferensi di Stockholm (1972); b) Konferensi di Nairobi dan WCED (1982); c) Konferensi Bumi di Rio de Janeiro (1992); d) Konferensi Rio (1997); e) Konferensi di Johannesbrug (2002)

Masyarakat Kuta memiliki kearifan lokal yang berkaitan dengan pengelolaan dan pelestarian lingkungan hidup. Penelitian yang dilakukan Adeng, dkk (2014:3) menyimpulkan masyarakat Kuta memiliki kesadaran dalam memanfaatkan dan menggunakan alam sesuai dengan fungsi sosial dan budaya yang tumbuh di lingkungan mereka. Artinya, masyarakat Kuta memahami alam dengan persepsi sosial dan kebudayaannya yang berfokus pada keyakinan religiusitas. Mereka tidak mengeksploitasi alam tetapi justru melindungi dan menjaga keberlangsungan alam sebagai sumber kehidupannya. Aturan sosial untuk menata aktivitas ekonomi dikontrol oleh tradisi yang telah hidup dari waktu ke waktu. Untuk memelihara dan menjaga tradisi mereka melakukan berbagai aktivitas ritual yang terkait dengan keberadaan warga masyarakat Kuta, sebagai suatu komunitas sosial. Semua sumberdaya alam yang ada di Leuweung Gede, menjadi bagian penting kehidupan masyarakat yang harus dijaga keberadaannya dengan suatu tradisi yang bersumber pada kegiatan keagamaan (religiusitas) misalnya pamali, dan kebiasaan sehari-hari yang terkait dengan kegiatan pertanian, atau sekitar rumah dan kampung. Kearifan lokal masyarakat Kuta dapat menjadi sumber inspirasi semua pihak dalam memelihara dan melestarikan lingkungan hidup.

Sehubungan dengan masalah pelestarian lingkungan hidup, Kementerian Pendidikan Nasional telah memasukan 
kepedulian pada lingkungan sebagai salah satu nilai dalam pendidikan karakter. Dalam Pedoman Pelaksanaan Pendidikan Karakter (Kemdiknas, 2011:3) terdapat 18 (delapan belas) nilai-nilai dalam pendidikan karakter, yaitu:

1. Relijius, sikap dan perilaku yang patuh dalam melaksanakan ajaran agama yang dianutnya, toleran terhadap pelaksanaan ibadah agama lain, dan hidup rukun dengan pemeluk agama lain.

2. Jujur, perilaku yang didasarkan pada upaya menjadikan dirinya sebagai orang yang selalu dapat dipercaya dalam perkataan, tindakan dan pekerjaan.

3. Toleransi, sikap dan tindakan yang menghargai perbedaan agama, suku, etnis, pendapat, sikap dan tindakan orang lain yang berbeda dari dirinya.

4. Disiplin, tindakan yang menunjukkan perilaku tertib dan patuh pada berbagai ketentuan dan peraturan.

5. Kerja Keras, tindakan yang menunjukkan perilaku tertib dan patuh pada berbagai ketentuan dan peraturan.

6. Kreatif, berpikir dan melakukan sesuatu untuk menghasilkan cara atau hasil baru dari sesuatu yang telah dimiliki.

7. Mandiri, sikap dan perilaku yang tidak mudah tergantung pada orang lain dan menyelesaikan tugas-tugas.

8. Demokratis, cara berfikir, bersikap dan bertindak yang menilai sama hak dan kewajiban dirinya dan orang lain.

9. Rasa Ingin Tahu, sikap dan tindakan yang selalu berupaya untuk mengetahui lebih mendalam dan meluas dari sesuatu yang dipelajarinya, dilihat dan didengar.

10. Semangat Kebangsaan, cara berpikir, bertindak dan berwawasan yang menempatkan kepentingan bangsa dan Negara di atas kepentingan diri dan kelompoknya.

11. Cinta Tanah Air, cara berpikir, bertindak dan berwawasan yang menempatkan kepentingan banga dan Negara di atas kepentingan diri dan kelompoknya.

12. Menghargai Prestasi, sikap dan tindakan yang mendorong dirinya untuk menghasilkan sesuatu yang berguna bagi masyarakat, dan mengakui, serta menghormati keberhasilan orang lain.
13. Bersahabat/Komunikatif, sikap dan tindakan yang mendorong dirinya untuk menghasilkan sesuatu yang berguna bagi masyarakat dan mengakui, serta menghormati keberhasilan orang lain.

14. Cinta Damai, sikap dan tindakan yang mendorong dirinya untuk menghasilkan sesuatu yang berguna bagi masyarakat, dan mengakui serta menghormati keberhasilan orang lain.

15. Gemar Membaca, kebiasaan menyediakan waktu untuk membaca berbagai bacaan yang memberikan kebajikan bagi dirinya.

16. Peduli Lingkungan, sikap dan tindakan yang selalu berupaya mencegah kerusakan pada lingkungan alam di sekitarnya dan mengembangkan upaya-upaya untuk memperbaiki kerusakan alam yang sudah terjadi.

17. Peduli Sosial, sikap dan tindakan yang selalu ingin memberi bantuan pada orang lain dan masyarakat yang membutuhkan.

18. Tanggung Jawab, sikap dan perilaku seseorang untuk melaksanakan tugas dan kewajibannya yang seharusnya dia lakukan, terhadap diri sendiri, masyarakat, lingkungan (alam, sosial dan budaya), Negara dan Tuhan Yang Maha Esa.

Dalam Pedoman Pelaksanaan Pendidikan Karakter pemerintah mempunyai perhatian yang besar terhadap pelestarian lingkungan. Hal ini tampak pada point ke 16 (enam belas) dari pedoman tersebut agar setiap warga negara memiliki kepedulian terhadap kerusakan alam dan sekitarnya serta melakukan upaya penyelamatan lingkungan.

Merujuk dari kenyataan-kenyataan diatas, kearifan lokal masyarakat Kuta berupa nilai-nilai religius, dan sosial budayanya dapat dijadikan materi pembelajaran Pendidikan Kewarganegaraan untuk membentuk karakter peserta didik yang memiliki kepedulian terhadap masalah lingkungan hidup. Nilai sosial budaya masyarakat Kuta sebagai modal sosial (social capital) yang harus digali dan dikembangkan dalam materi dan strategi pembelajaran Pendidikan Kewarganegaraan. 


\section{METODE PENELITIAN}

Penelitian ini menggunakan metode penelitian kualitatif deskriptif. Penelitian deskriptif bersifat pemaparan dan bertujuan untuk memperoleh gambaran lengkap tentang keberadaan komunitas tertentu yang berdiam di tempat tertentu, atau mengenai gejala sosial tertentu, atau peristiwa hukum tertentu yang terjadi dalam masyarakat.

Teknik pengumpulan data dengan literature study dari laporan penelitian, artikel ilmiah yang diterbitkan secara rutin ataupun berkala yang relevan dengan fokus kajian dan memiliki nilai epistemic values yang sangat berguna untuk mendapatkan pengetahuan atau informasi. Sumber data yang lain diperoleh dari foto dokumentasi yang memuat peristiwa nyata yang tidak dapat dibantah karena orisinalitas substansi terletak pada foto tersebut (Al Muchtar, 2015)

Analisis data dilakukan dengan cara: a) reduksi data, memilih dan menyederhanakan data yang diperoleh dari berbagai sumber literatur dan artikel; b) penyajian data, dilakukan dalam bentuk uraian singkat dan gambar; c) verifikasi dan kesimpulan yaitu melakukan kegiatan pengecekan dan intepretasi data dari literatur dan dokumentasi untuk kemudian dibuatkan kesimpulan yang jelas dan akurat mengenai hasil penelitian (Moleong, 2000:190)

\section{HASIL PENELITIAN DAN PEMBAHASAN}

\section{Kearifan Lokal di Indonesia}

Wacana tentang kearifan lokal di Indonesia sebenarnya sudah lama dibicarakan sekitar tahun 1980an, ketika nilai-nilai budaya lokal Indonesia yang merupakan warisan nenek moyang sudah hampir punah dilindas oleh derasnya arus modernisasi yang menjadi kebijakan dasar pembangunan yang dilaksanakan oleh orde baru. Modernisasi yang membuka diri kepada globalisasi, ditambah oleh semangat nasionalisme yang menginginkan agar di seluruh Indonesia kehidupan masyarakat seragam. Dengan demikian kekayaan budaya lokal baik berupa seni, sastra, hukum adat dan lain-lain banyak yang hanyut dan hilang, sehingga tidak bisa digunakan sebagai pemerkaya khasanah budaya nasional yang hendak dibangun (Rosidi, 2011:35)

Kearifan lokal merupakan bentuk budaya dari daya tahan dan daya tumbuh yang diwujudkan melalui pandangan hidup, pengetahuan, dan pelbagai strategi kehidupan yang berupa aktivitas yang dilakukan oleh masyarakat lokal untuk menjawab berbagai masalah dalam pemenuhan kebutuhan hidupnya sekaligus menjaga dan memelihara kebudayaannya. Dalam pengertian inilah kearifan lokal sebagai jawaban untuk bertahan dan menumbuhkan secara berkelanjutan kebudayaan yang didukungnya. (Kementerian Kebudayaan dan Pariwisata, 2011:10)

Kearifan lokal berbentuk tradisi lisan, dan lebih banyak tumbuh dan berkembang di daerah pedesaan. Pengetahuan itu dikembangkan karena adanya kebutuhan untuk menghayati, mempertahankan, dan melangsungkan hidup sesuai dengan situasi, kondisi, kemampuan dan nilai-nilai yang dihayati didalam masyarakatnya. Oleh sebab itu, pengetahuan lokal menjadi bagian dari cara hidup mereka yang arif, supaya dapat memecahkan berbagai permasalahan hidup yang mereka hadapi, sehingga mereka dapat meneruskan kehidupannya, bahkan dapat berkembang secara berkelanjutan.

Sementara itu, kearifan lokal menurut Nuraeni dan Alfan (2012:68) adalah nilai-nilai yang berlaku dalam suatu masyarakat; nilainilai yang diyakini kebenarannya dan dijadikan acuan dalam melakukan aktivitas masyarakat setempat. Secara subtansial, kearifan lokal itu adalah nilai-nilai yang berlaku dalam suatu masyarakat. Nilai-nilai sosial budaya selanjutnya menjadi tradisi masyarakat setempat. 
Wagiran (2012:333) mengemukakan dimensi fisik dari kearifan lokal, meliputi: 1) upacara adat; 2) cagar budaya; 3) pariwisata alam; 4) transportasi tradisional; 5) permainan tradisional; 6) prasarana budaya; 7) pakaian adat; 8) warisan budaya; 9) museum; 10) Lembaga budaya; 11) kesenian; 12) desa budaya; 13) kesenian dan kerajinan; 14) cerita rakyat; 15) dolanan anak; dan 16) wayang.

Dimensi fisik kearifan lokal tersebut setidaknya menyiratkan beberapa konsep, yaitu kearifan lokal adalah sebuah pengalaman Panjang yang telah dilalui, yang kemudian diendapkan sebagai petunjuk seseorang; kearifan lokal tidak lepas dari lingkungan masyarakat adat sebagai pemiliknya, selain itu terkait dengan budaya masyarakat yang terakumulasi dan diwariskan kepada generasi berikutnya, dan kearifan lokal ini bersifat dinamis, lentur, terbuka, dan selalu menyesuaikan dengan perkembangan jamannya. Konsep demikian juga sekaligus memberikan gambaran bahwa kearifan lokal selalu terkait dengan budaya masyarakat yang turun temurun. Kearifan lokal ini muncul sebagai penjaga atau filter iklim global yang melanda kehidupan manusia.

Kearifan Lokal yang sering dikonsepsikan sebagai pengetahuan setempat (local knowledge), kecerdasan setempat (local genius), dan kebijakan setempat (local wisdom) oleh Undang-Undang Republik Indonesia Nomor 32 Tahun 2009 tentang Perlindungan dan Pengelolaan Lingkungan Hidup dimaknai sebagai nilai-nilai luhur yang berlaku dalam tata kehidupan masyarakat yang antara lain dipakai untuk melindungi dan mengelola lingkungan hidup secara lestari.

\section{Budaya Masyarakat Kuta Wujud Kearifan Lokal}

Masyarakat Kuta tinggal di daerah Ciamis. Wilayahnya dikelilingi oleh tebingtebing (kuta) dengan ketinggian antara 100 sampai 150 Meter dari atas permukaan laut.
Kampung Kuta dihuni sekitar 123 Kepala Keluarga, kehidupan masyarakatnya masih terikat kuat dengan adat istiadat warisan leluhur dan harus dipertahankan. Kuatnya masyarakat dalam mempertahankan adat istiadat itu diduga karena keluarga berperan aktif dalam mensosialisasikan kepada seluruh anggota keluarganya (Soedarmo dan Suryana, 2019:86).

Masyarakat Kuta memiliki banyak kebiasaan sebagai petunjuk perilaku masyarakatnya. Dalam adat istiadatnya tersebut ada aturan-aturan dianggap baik sehingga dapat dilakukan dan aturan-aturan yang dianggap tidak baik yang tidak boleh dilakukan. Hal ini sangat dipatuhi oleh masyarakatnya, karena pelanggaran terhadap adat istiadat dapat berdampak kurang baik bagi kehidupan masyarakat Kuta

Penelitian Soedarmo dan Suryana (2019:93-94) menunjukkan beberapa ketentuan dari adat istiadat yang harus ditaati oleh masyarakat Kuta dalam memelihara dan menjaga kelestarian lingkungan hidup:

a. Leuweung Gede hanya boleh dimasuki pada hari Senin dan Jumat. Hal ini dikaitkan dengan cerita sejarah tentang tokoh $\mathrm{Ki}$ Bumi dan $\mathrm{Ki}$ Batasela saat mereka pertama kali memasuki Leuweung Gede.

b. Tidak boleh meludah, buang air kecil, dan besar karena dapat mengotori kesucian tempat tersebut.

c. Saat memasuki Leuweung Gede tidak diperbolehkan membawa peralatan yang terbuat dari besi seperti golok dan sabit karena dengan membawa alat tersebut memungkinkan seseorang melakukan penebangan terhadap pohon-pohon yang menghalangi jalan misalnya, padahal pohon itu milik leluhur yang sengaja ditanam dan dipelihara.

d. Tidak boleh menangkap apalagi membunuh binatang yang ada di Leuweung Gede. Larangan ini didasari keyakinan bahwa makhluk gaib yang menghuni leuweung itu adalah makhlukmakhluk sakti yang bisa mancala putra mancala putri. 
e. Tidak boleh membuang sampah yang mengandung api. Larangan ini bermula dari kebiasaan $\mathrm{Ki}$ Bumi yang menuru mitos ia akan memadamkan rokok yang tengah dihisapnya manakala memasuki Leuweung Gede.

Berkenaan dengan aturan memasuki Leuweung Gede tersebut dapat disimpulkan bahwa aturan tersebut dibuat semata-mata untuk memelihara dan menjaga kelestarian lingkungan hidup, karena perusakan dan pencemaran lingkungan dapat terjadi ketika masyarakat menebang pohon tanpa mengindahkan manfaat dan fungsi hutan yang menjadi sumber kehidupan masyarakat Kuta, serta untuk mencegah adanya pencemaran atau polusi udara ketika ada yang memasuki hutan dengan membuang puntung rokok sembarangan yang dapat mengakibatkan bahaya kebakaran.

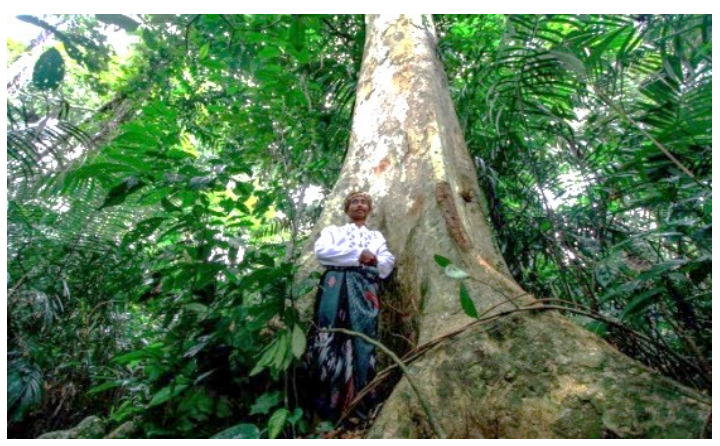

Gambar 1

Hutan Karamat (Leuweung Gede)

Masyarakat Kuta juga memiliki aturan mendirikan rumah yang berkaitan dengan pelestarian lingkungan hidup (Soedarmo dan Suryana, 2019:92):

a. Teya, kegiatan ini merupakan penentuan apakah tanah yang akan digunakan untuk membangun rumah itu cocok atau tidak dengan yang akan menghuninya. Untuk mengetahui cocok tidaknya, pada malam weton yang jatuh hari pasar kliwon atau pada malam Jum'at kliwon, ditanah yang akan dibangun disimpan sesajen berupa: segelas air (gelasnya terbuat dari potongan bambu yang ada ruasnya), dan beberapa rangggeuy pare yang setelah disimpan ditengah areal kemudian ditutup dengan aseupan bekas. Jika keesokan harinya air yang ada dalam gelas tidak berkurang, ranggeuyan pare tidak ada yang jatuh, dan ditemukan semut ateul, pertanda tanah itu cocok untuk dibangun dan pembangunan pun bisa di mulai.

b. Ngalelemah, yaitu kegiatan untuk meratakan tanah sehingga kondisinya memungkinkan untuk membangun rumah.

c. Dinding rumah harus terbuat dari bilik (irisan bamboo yang dianyam) atau terbuat dari papan kayu.

d. Pintu dan jendela harus gebyog, yaitu daun pintu dan jendela yang seluruh bahannya terbuat dari papan.

e. Tiang penyangga utama rumah harus diletakkan di atas tatapakan yang terbuat dari batu alam berbentuk pipih atau persegi Panjang.

f. Lantai rumah harus terbuat dari palupuh (bamboo yang dipipihkan) atau lempengan papan.

g. Hari Jum'at pertama setelah rumah di huni, penghuni wajib menanam tiga jenis tanaman yaitu: kelapa, pisang, dan ketela pohon disekitar rumahnya.

Dari aturan tersebut dapat dijelaskan bahwa masyarakat Kuta dalam mendirikan bangunan tetap memperhatikan aspek lingkungan hidupnya. Rumah yang didirikan menggunakan material yang ada di alam (kayu, rumbia, bamboo), tanpa harus merusak alam itu sendiri. Tidak ada rumah yang berdinding tembok dan beratap genteng.

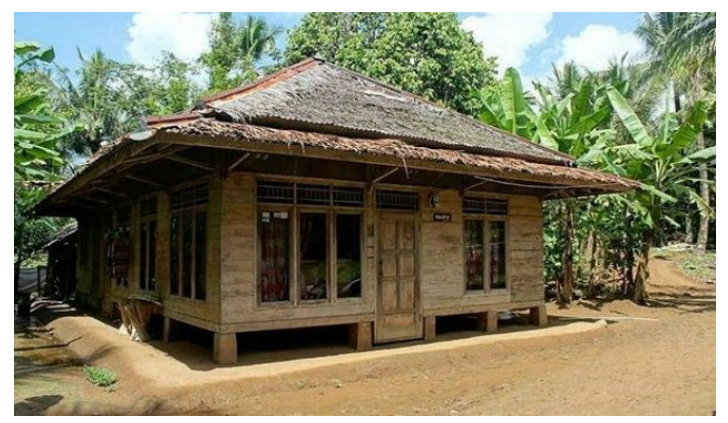

Gambar 2

Rumah Tanpa Tembok 


\section{Pembelajaran PKn Berbasis Kearifan Lokal}

Mengingat pentingnya karakter bangsa yang memiliki wawasan lingkungan, maka PKn sebagai instrumen untuk membangun warga negara yang baik (good citizenship) dalam upaya pembangunan karakter bangsa harus memperhatikan nilai-nilai budaya tentang pelestarian lingkungan yang ada di masyaraka $t$ Indonesia jika tidak akan menimbulkan ketidakpastian jatidiri bangsa (Ramdani, 2018:4). Senada dengan yang dikemukakan Ramdani, menurut Marzuki, dkk. (2011:47) bahwa karakter identik dengan akhlak, jalinan hubungan antara manusia dengan Tuhan, dan makhluk hidup lainnya yang diatur dalam ajaran agama, tata krama, budaya, hukum, dan kebiasaan-kebiasaan yang ada di masyarakat.

Pembelajaran PKn berbasis kearifan lokal masyarakat Kuta berarti menjadikan nilai-nilai yang terkandung dalam budaya lokal masyarakat Kuta sebagai sarana pembangunan karakter bangsa. Integrasi nilainilai kearifan lokal masyarakat Kuta kedalam PKn merupakan strategi pembentukan kewarganegaraan ekologis.

Berdasarkan Kepdirjendikti (2020) tentang Pedoman Pelaksanaan Mata Kuliah Wajib Pada Kurikulum Pendidikan Tinggi substansi Pendidikan Kewarganegaraan meliputi: a) Pengantar Pendidikan kewarganegaraan; b) identitas nasional; c) integrasi nasional; d) konstitusi Indonesia; e) kewajiban dan hak negara dan warga negara; f) dinamika demokrasi di Indonesia; g) penegakan hukum di Indonesia; h) wawasan nusantara; i) ketahanan nasional.

Merujuk kepdirjendikti tersebut subtansi PKn belum secara eksplisit mencantumkan tentang Lingkungan Hidup. Mengingat bahwa kerusakan dan pencemaran lingkungan yang terjadi sudah semakin meluas perlu mendapatkan perhatian khusus berupa aksi penyelamatan lingkungan. Gerakan penyelematan lingkungan sebenarnya merupakan bagian dari gagasan kewarganegaraan ekologi. untuk mempengaruhi pola pikir dan tingkah laku manusia dalam berinteraksi dengan alam.

Sekaitan dengan Gerakan penyelamatan lingkungan tidak terlepas juga dengan sosial maka menurut (Widodo dan Nurholis 2019: 49) Pendidikan Kewarganegaraan dapat menguatkan karakter bangsa untuk meminimalisir terjadinya bencana sosial. Jadi

Pendidikan lingkungan hidup dalam pembelajaran PKn berbasis kearifan lokal masyarakat Kuta, meliputi komponenkomponen sebagai berikut:

a. Tujuan Pembelajaran

Untuk menghasilkan peserta didik memiliki pengetahuan tentang lingkungan hidup, sikap sadar dan peduli lingkungan, dan berperan aktif dalam mewujudkan lingkungan hidup yang baik dan sehat.

b. Bahan Pembelajaran

Berkaitan dengan nilai-nilai sosial budaya atau adat istiadat masyarakat Kuta baik dalam bentuk buku pelajaran sejarah budaya Indonesia, kajian, artikel ilmiah, dan dokumentasi.

Kearifan lokal masyarakat Kuta dapat dijadikan sebagai rujukan atau contoh pembelajaran karakter berwawasan lingkungan. Untuk menumbuhkan kesadaran masyarakat akan pentingnya menjaga alam demi kehidupan yang seimbang antara manusia dan alam sekitarnya. Pembelajaran PKn perlu memuat materi tentang pengelolaan, pelestarian, dan penegakan hukum lingkungan. Nilai kearifan lokal masyarakat kampung Kuta dapat menjadi sumber belajar tentang etika dan tata lingkungan, pentingnya keselaran hubungan manusia dengan alam, pemanfaatan sumber daya alam yang terkendali dan meminimalisir kerusakan, upaya cagar alam serta bagaimana pembangunan berwawasan lingkungan. 
c. Strategi dan Metode Pembelajaran

Pendidik harus mampu menguasai dengan mempertimbangkan segala aspek baik tujuan instruksional, alokasi waktu, kemampuan peserta didik, jumlah peserta didik dan materi yang akan disampaikan. Metode pembelajaran dapat ditekankan pada pemecahan masalah.

d. Media Pembelajaran

Media pembelajaran seperti Laptop, Komputer, dan $L C D$ dapat digunakan untuk pemutaran film yang menggambarkan kehidupan sehari-hari masyarakat Kuta. Karakter masyarakat Kuta dapat disajikan dengan lebih menarik. Hal ini akan menarik dan mengundang keterlibatan peserta didik dalam peristiwa-peristiwa yang diperlihatkan. Pada akhirnya dapat untuk mempengaruhi pola pikir dan tingkah laku peserta didik dalam berinteraksi dengan alam sekitarnya.

e. Evaluasi Pembelajaran

Dilaksanakan dengan penilaian otentik yang bersifat komprehensif yang meliputi tes tertulis, sikap, perbuatan, produk dan portfolio.

f. Pendidik dan Peserta Didik

Pendidik harus menguasai materi yang akan diajarkan. Peserta didik merupakan pribadi yang otonom yang ingin mengembangkan diri secara terus menerus untuk meghadapi dan mengatasi masalahmasalah hidup yang dijumpai sepanjang hayatnya.

Pembelajaran

Kewarganegaraan sebagai pendidikn lingkungan hidup yang merujuk pada kehidupan sehari-hari masyarakat Kuta yang sarat akan nilai-nilai budaya dalam memelihara lingkungan dapat membentuk karakter warga negara yang sadar dan peduli terhadap lingkungan dan mempunyai kemampuan dalam memecahkan segala masalah lingkungan. Hubungan timbal balik yang baik antara makhluk hidup, khususnya manusia dan lingkungan hidup akan menciptakan lingkungan hidup yang baik, sehat dan asri. Makhluk hidup yang lain itu bukanlah sekedar kawan hidup yang hidup bersama secara netral atau pasif terhadap manusia, melainkan hidup manusia itu terkait erat pada mereka. Tanpa mereka manusia tidaklah dapat hidup.

\section{KESIMPULAN}

Masyarakat Kuta mempunyai kearifan lokal, berupa: a) Aturan berperilaku seharihari; b) Aturan memasuki hutan Karamat atau Leuweung Gede; c) Aturan membangun rumah; d) norma-norma lainnya yang terdiri dari anjuran, larangan, sanksi, dan ungkapanungkapan. Kearifan lokal tersebut digunakan dan dilaksanakan sebagai pedoman masyarakat dalam mengelola dan melestarikan lingkungan hidup. Budaya lokal masyarakat Kuta merupakan salah satu kearifan lokal yang harus dipertahankan sehingga nilai sosial budaya tersebut akan menjadi identitas budaya lokal.

Pendidikan Kewarganegaraan mempunyai peranan yang strategis dalam membentuk karakter warga negara yang memiliki wawasan lingkungan hidup. Pendidikan Kewarganaegaraan yang berwawasan lingkungan ini penting agar kepedulian akan lingkungan hidup ini bertambah baik dan untuk menekan kerusakan ataupun pencemaran lingkungan. Karakter peduli lingkungan ini menyatu kedalam diri setiap individu sebagai pola pikir, sikap, dan tindakannya.

\section{DAFTAR PUSTAKA}

Adeng, D. (2014). Kajian Kearifan Lokal Di Kampung Kuta Kabupaten Ciamis. Bandung: CV Izda Prima.

Al Muchtar, S. (2015). Dasar Penelitian Kualitatif. Gelar Pustaka Mandiri.

Fitriasari, S. (2017). Pengembangan Pembelajaran Pendidikan

Kewarganegaraan Berbasis "Green Constitution" Untuk Menumbuhkan Keadaban Kewarganegaraan Terhadap Lingkungan. Disertasi. Tidak Dipublikasikan. SPs UPI.

Herlina, N. (2015). Permasalahan Lingkungan Hidup Dan Penegakan Hukum 
Lingkungan Di Indonesia. Jurnal Ilmiah GALUH JUSTISI, 3 (2), 1-15.

Kementaerian Kebudayaan dan Pariwisata. (2011). Kearifan Lokal Di Tengah Modernisasi.

Kemdiknas. (2011). Pedoman Pelaksanaan Pendidikan Karakter.

Kepdirjendikti Nomor 84/E/KPT/2020, K. (2020). Pedoman Pelaksanaan Mata Kuliah Wajib Pada Kurikulum Pendidikan Tinggi. Kemendikbud.

Marzuki, D. (2011). Pembinaan Karakter Siswa Berbasis Nilai Agama. Jurnal Pendidikan, 41 (1), 45-53.

Moleong, L. J. (2000). Metodologi Penelitian Kualitatif. Bandung: PT REMAJA ROSDAKARYA.

Nuraeni, H. G., dan Alfan, M. (2012). Studi Budaya di Indonesia. Bandung: CV Pustaka Setia.

Ramdani, E. (2018). Model Pengembangan kontekstual Berbasis Kearifan Lokal Sebagai Penguatan Pendidikan Karakter. Jurnal Pendidikan Ilmu-Ilmu Sosial, 10 (1), 1-10.

Rosidi, A. (2011). Kearifan Lokal: Dalam Perspektif Budaya Sunda. Bandung: PT Kiblat Buku Utama.

Soedarmo, U.R., dan Suryana, A. (2019). Peran Keluarga Dalam Sosialisasi Adat Istiadat Komunitas Dusun Kuta. Jurnal Artefak, 6 (2), 85-98.

Soemarwoto, O. (2001). Ekologi, Lingkungan Hidup dan Pembangunan. Jakarta: Djambatan.

Suparni, N. (1994). Pelestarian, Pengelolaan, dan Penegakan Hukum Lingkungan. Jakarta: Sinar Grafika.

Undang-Undang Dasar Negara Republik Indonesia Tahun 1945. Sekretariat Negara.

Undang-Undang Nomor 32 tentang (2009). Perlindungan dan Pengelolaan Lingkungan Hidup.
Wagiran. (2012). Pengembangan Karakter Berbasis Kearifan Lokal Hamemayu Hayuning Bawana (Identifikasi Nilainilai Karakter Berbasis Budaya). Jurnal Pendidikan Karakter, 2 (3), 329-339.

Widodo, B \& Nurholis, E. (2019). Revitalisasi Epistemologis Pendidikan Kewarganegaraan: Upaya Meminimalisir Bencana Sosial. Ciamis: Jurnal Artefak, 6 (2), 49-58.

Yuniarto, B. (2011). Membangun Kesadaran Warga Negara Untuk Pelestarian Lingkungan. Tesis. Tidak Dipublikasikan. UPI. 
Jurnal Artefak:

Vol.8 No.1 April 2021 [1-10] 